\title{
Archiving star labour: (re)framing Vivien Leigh
}

\section{Lisa Stead}

\begin{abstract}
This article seeks to complicate dominant narratives surrounding the star image of stage and screen star Vivien Leigh by interrogating how the material traces of her working life are retained within her dispersed archives. Leigh's archives document both the development of her stage and screencraft and her alternative off-screen 'roles' in business, philanthropy and activism throughout her transatlantic career, spanning the 1930s to the 1960s. By exploring materials such as annotated scripts, correspondence and photographs, the article examines how Leigh's process of archiving produced distinct framings of her multifaceted labour for the future archival spectator. I argue that Leigh's archival self-fashioning constitutes a complex material network, one which offers alterative readings of gendered star labour and pushes back against more standardised narratives of her career that have overwhelmingly focused on her glamorous star image, her mental health, and her relationship with her equally famous husband and co-star Laurence Olivier.
\end{abstract}


This article interrogates the role that the star archive can play in illuminating and (re)framing histories of female star labour, focusing as a case study on Vivien Leigh (1913-1967) and her dispersed archival collections. Leigh began her career on the English stage and screen in the 1930s and went on to achieve global film stardom with her Oscar-winning roles in Gone with the Wind (1939)1 and A Streetcar Named Desire (1951)2, working on both sides of the Atlantic as one half of the 'royal couple' of British acting with her co-star husband Laurence Olivier. Whilst Leigh's life has been documented in a steady stream of popular biographical publications since her death in 1967,3 relatively scant academic work has been produced on her career and star image. This article seeks to address this gap.

In doing so, however, my intention is not to produce a more standard analysis of the constructed nature of Leigh's status as star 'text'. Instead, the article interrogates Leigh's archival legacy, considering the meanings of the complex network of archival fragments that constitute her globally dispersed collections - including correspondence, script annotations, photography and ephemera - in relation to her status as a working actress. Combining a specific strand of star studies that focusses on theorising and historicising star labour with archival methodologies, the article seeks to 'reframe' Leigh by focusing on her creative labour. This new focus offers an alternative way to interpret her cultural legacy and her identity as a female performer working within the transatlantic film industries of the inter and post-war years.

There are two sub-strands of this investigation: that of Leigh's alternative off-screen 'roles' between the 1930s and 1960s in business and philanthropy protestor, and that of Leigh's labour as a performer, researching, crafting and developing her stage and screen roles independently and in collaboration. Material analysis of the documentation of these modes of 
gendered labour facilitates a broader exploration of how the retention of such artefacts foregrounds Leigh's archival self-fashioning. As such, the article simultaneously seeks to reflect on her role as the preserver and curator of the material history of her working life. Antoinette Burton describes the 'backstage of archives' as an important consideration in our scholarly interactions with their contents, where attention should be given to 'how they are constructed, experienced and manipulated'.4 I suggest that bringing such 'backstage' considerations to bear on Leigh's archival documentation of her working life and the placement and visibility of such documentation across archival institutions is essential to understanding how such collections make meaning. Bringing the backstage to the foreground allows us to break with the conventions of scholarly discourse which focus on telling 'a story about what you found, but not about how you found it.' 5 In foregrounding the story of 'how', I suggest that we can consider how both the composition of the archive and the details of specific archival documents facilitates a reframing of stars like Leigh within popular and critical discourse.

\section{'A consummate actress, hampered by beauty'}

Leigh's star image is most often framed in relation to three core aspects. These include her most famous screen roles as Scarlett O'Hara in GWTW and Blanche DuBois in Streetcar; her struggles with mental health; and her affair, marriage and working relationship with stage and screen star Laurence Olivier. As previously mentioned, Leigh twice won the Academy Award for Best Actress in these two prominent roles, and her star image has often been conflated with the characters, specifically in regard to Blanche DuBois, who, like Leigh, struggles with mental health. For Leigh, such struggles became headline news when her breakdown in 1953, amidst the filming of the movie Elephant Walk, was reported in national and international newspapers. In regard to her famous marriage, through their working and 
romantic partnership Leigh and Olivier became known as the 'royal couple' of British acting, consolidating their star power through theatrical tours and varied film work. For Leigh particular, her stardom instigated a highly active fan following that extends into the present moment. Celebratory events held in Leigh's honour in London in 2017, for example, marked the longevity of her fan club 'The Vivien Leigh Circle', founded in the late 1960s and 'reignited' in the 2010s.6

Press interest in the acquisition of Leigh's personal archive by the Victoria \& Albert Museum in 2013 reveals the persistence of these frameworks for interpreting her cultural legacy. Press coverage focused on the archive's potential to offer new intimate details about her initial affair and later marriage to Olivier, for example, with The Guardian promising readers a new expose of the couple's unseen 'steamy love letters'.7 Whilst Leigh's personal and working relationship with Olivier and her difficulties with mental illness significantly impacted on her working life, the dominance of these factors in accounts of her cultural legacy has limited attention to her agency as a professional stage and screen performer and working woman. In seeking to 'reframe' Leigh in this way, I draw upon approaches to star studies that have emphasised star labour, breaking with a narrower focus upon star image alone within more conventional star studies methodologies. Danae Clark's work on the cultural politics of actors' labour, for example, has sought to relocate the star within the sphere of production. She foregrounds the role of the star 'as a social subject who struggles within the film industry's sphere of productive practices', moving beyond a primary focus on the 'spectatorimage relationship' in order to foreground 'the conditions of labor that produce that image.' 8 Such accounts offer an alternative entry point for star analysis, but they remain more abstract in their methodology. Sean Holmes has sought, for example, to give greater attention to 'the star system in Hollywood as a lived experience',9 calling for a move away from more 
abstract theoretical analyses of star labour and toward a con-sideration of 'the men and women who worked in the motion picture studios' and 'their day-to-day experiences on the cinematic shop floor'.10 In order to examine such experiences in 1920s and 1930s Hollywood, Holmes turns to archival materials such as the Actors' Equity Associations Collection held at the Wagner Labour Archives, and the Academy of Motion Picture Arts and Sciences Collection at the Margaret Herrick Library, tracing the experience of a range of performers 'at every level of the Hollywood star system.'11

In contrast, my interest centres upon a specific star case study and upon the star archive, shifting focus more acutely to the process of how an individual's labour is documented and articulated through the archive as a specific mode of self-fashioning. I argue that the star archive offers one distinct access point to understanding how female stars as one distinct subset of the wider spectrum of acting professionals within the transatlantic film industries have sought to articulate their experiences as workers through particular material traces of their labouring lives. Close examination of star archives can also open up alternative ways of thinking about star labour beyond their interactions within studios alone. Leigh's collections evidence the multiplicity of activities with which she was professionally engaged across her lifetime in tandem with her film and stage work, for example, documenting philanthropic and business activities in particular. Whilst these activities are not atypical for many female stars in this period, Leigh's individual approach to documenting these labours through the personal archival collection merits closer attention, particularly given the lack of any star autobiography or memoir by Leigh.

There is no easily defined single 'archive' for Vivien Leigh, however. The V\&A hold a substantial 'Vivien Leigh archive', but materials related to Leigh can be found in various 
other collections; namely those of her husband, Laurence Olivier. The Olivier collection at the British Library, for example, contains an extensive 'Vivien Leigh Papers' subsection. Materials can also be found at major repositories such as the Harry Ransom Centre in Texas in collections related to David O. Selznick and the making of GWTW, at the British Film Institute in London, which holds a collection of letters between Leigh, Jack Merivale and Olivier, and in smaller, regional centres, such as the Royal Albert Memorial Museum in Exeter, the Bristol Old Vic archive at the University of Bristol, and Topsham Museum in the South West of England. Topsham holds a nightdress worn by Leigh in the filming of GWTW, for example, along with dozens of other personal and professional items of dress and theatrical paraphernalia retained by the museum's founder Dorothy Holman, the sister of Leigh's first husband, Herbert Leigh Holman.

Leigh's archival collections have thus far been utilised more in the service of memorialisation and the reproduction of her star image than an examination of her working life. In publicly touring the newly acquired Leigh archive in $2015-16$, for example, the V\&A created a 'Vivien Leigh: Public Faces, Private Lives' exhibition that profiled her experience in filming GWTW and her interactions with fashion photographers and designers, and presented a wealth of personal material about her life prior to stardom. Whilst the exhibition focused, as its subtitle emphasised, on Leigh's public as well as private life, the brochure featured a telling quotation from British actress Gladys Cooper claiming that Leigh 'should be in a museum, for history's sake, as the famous beauty of the English stage.'12 Cooper's assessment reinforces a pervasive sense of the preservation of Leigh's body, and by extension her glamorous star image, as her primary source of value and meaning making. Indeed, the display of star archive ephemera in such exhibitions capitalises on the desire of spectators to make present the absent star body through interaction with costumes, jewellery, photographs, 
or traces of Leigh's hand-writing, getting as close as possible to the things that Leigh touched, created and wore in her lifetime.

This intensely bodily emphasis is, of course, not unwarranted given the primacy of the stars' bodily image in their meaning and status as cultural figures and as visual culture commodities. In Leigh's case, however, obsessive attention to her physical appearance constituted an ongoing discourse of both praise and critique that impacted her working life in distinctly gendered ways. Kate Dorney observes that 'in press reports, interviews, books and articles she remains chiefly characterised in relation to her beauty', tied strongly to notions 'of experience and inexperience'13 that had shaped the reception of her star persona from her first significant stage appearance in The Mask of Virtue in 1935, where she was praised for her sensational physical presence despite her lack of acting experience. Leigh's 'discovery' story has been an important part of her popular culture mythology, emphasising her physical beauty above all else as key to the sensational reception of the play and to British producer/director Alexander Korda’s unprecedented offer of a $£ 50,000$ contract for ten films in five years. This led to a recurrent focus in press coverage across her career on the idea that her stage presence was 'a device contrived to disguise a lack of "technique", where her 'mental and physical application to the process of acting was [ ... ] frequently presented as an indication of her lack of talent.'14 Leigh's 'natural' beauty was seen to operate in compensation for her lack of craft, therefore, but her efforts at developing said craft were in turn criticised as compensation for a lack of 'natural' acting talent.15 George Cukor, Leigh's first director on GWTW, summarised this conflict when he famously referred to her as 'a consummate actress hampered by beauty'.16 Orson Welles similarly described 'her greatness as an actress [ ... ] in spite of her good looks'.17 Leigh herself remarked in a 1961 interview 
that '[p]eople think that if you look fairly reasonable, you can't possibly act, and as I only care about acting, I think beauty can be a great handicap'. 18

Leigh's conflicted relationship with the notion of performance as labour relates to the specific nature of performative labour as an 'act'. As Barry King describes:

The private labour of a dancer, musician or actor is not performance but practice. The elements of such an anterior activity clearly enter into the performance, but only as elements of signification in relation to the performance itself. Indeed, signs of practice - automatisms of movement, phrasings and speech - are generally regarded as a sign of deficiency in a performer.19

Evidence of practice within performance signals the inability to mask the labour of preparation -'performance qua performance never has a private character'20 in this sense. Leigh did not attempt such masking in her public commentary on her acting practice, where in interviews she spoke openly about her preparation and work in developing her characterisations, supported by her professional schooling at The Royal Academy of Dramatic Art and her ongoing training with voice and singing teachers. For Leigh, there-fore, we might summarise that cultivating a glamorous physical star image was a way of escaping the risk of showing signs of practice, but in turn risked attracting criticism as a means to hide a lack of skill underneath; whereas abandoning physical glamour in aid of a more authentic performance required intensive practice, but left no such aesthetic spectacle to smooth the signs of that practice within the performance, leading to a risk of criticism of deficiency and lack of 'natural' charisma. These critiques created an impossible bind that clearly frustrated her in her efforts to be taken seriously as a legitimate actress throughout her working life. 


\section{Star labour in the archive}

As collations of disparate, largely paper-based materials, Leigh's archives invite but do not simplistically define interpretations of her working life. Two distinct artefacts offer a productive entry point into beginning to unpack the presentation of her labours within her varied collections. The first is a cover for the American magazine $L O O K$ from 17 December 1940, a general-interest periodical published bi-weekly by Look, Inc. from the late 1930s to mid-1940s. The magazine cover was displayed by the National Portrait Gallery, London, as part of the Starring Vivien Leigh: A Centenary Celebration which ran from November 2013 to July 2014.21 Set against an arresting background of red white and blue stripes, the cover image depicts Vivien Leigh knitting blue yarn from a bag emblazoned with 'BUNDLES FOR BRITAIN'.

The second artefact, to which I shall return later in the article, offers a distinct contrast with $L O O K$ as a fragment of mass-produced ephemera in its status as a 'unique' archival artefact emerging from Leigh's personal archive at the V\&A. It is a short-handwritten note on a fragment of writing paper in Leigh's own hand, contained within her personal collections at the V\&A. This is an extract from an ongoing exchange with director Elia Kazan between late 1949 and early 1950 during preparation for Leigh playing the role of Blanch DuBois in the 1951 screen adaptation of Streetcar. The first section of the note, seemingly written during or in preparation for a telephone conversation with Kazan in 1950, explains that in relation to the way she would appear before the camera, she 'meant right not good'.22

The first image from the LOOK magazine cover frames Leigh as a specific celebrity sub-set of the war-time labourer. Her portrait functions as propagandistic national symbol during a 
period where her star image was under attack. When Britain announced its entry into the war in September 1939, Leigh was in the United States where she had been filming GWTW since January. She went on to star in Waterloo Bridge (1940) and Lady Hamilton (1941), both shot in the United States, and to tour with a production of Romeo and Juliet, meaning that she did not return to the UK until late in 1941, which caused considerable backlash from branches of the British press and British fan magazine writers who questioned her patriotism.23 Kendra Bean has discussed Leigh's desire to con-tribute to the war effort in the early forties, including 'volunteering as an ambulance driver, an auxiliary policewoman, or doing fire watch duty'.24 Leigh's practical contributions came in the form of radio broadcasting, appearances at charity events, serving tea to the troops and participating in initiatives such a Natalie Wales Latham's 'Bundles for Britain', featured here in the $L O O K$ cover, by knitting woollens for soldiers.

The presentation of Leigh's off-screen war work at this time has other stories to tell, however, when we focus on the status of the $L O O K$ magazine as a piece of archival ephemera. It gestures towards the other kinds of off-screen labours she undertook across her career that can be found within her archive through other examples of this kind of ephemera, and through photographs, correspondence, and fan letters. Archived materials from Leigh's personal correspondence, her scrapbooks and her financial records in her V\&A and British Library collections offer the chance to think about Leigh as a shrewd investor and business woman, for example. One significant area of her working life in the 1950s was her role as a producer with Laurence Olivier Productions (LOP), established to handle Olivier's stage productions and help finance Richard III (1955) and The Prince and the Show-girl (1957), and with V.L. Productions Ltd., reported in an archived clipping from the Edinburgh Evening News in 1958 as a new venture in 'the presentation side of the theatre.' 25 Other materials in 
her V\&A archive such as collections of production stills, head shots and costume sketches document her work with costume designers and fashion designers. These include collaborations with Lucinda Ballard and Oliver Messel (who designed her famous headdress for her role as Cleopatra), and her work as a model, featuring in Vogue in the mid-1930s. Elsewhere in her collections, the archival researcher can trace through correspondence her work as an actor-ambassador for the British Council in the late 1940s, and her philanthropic activities working with UNICF in the 1960s. Her work in leading and organising protests and mounting a campaign against the demolition of the St. James's Theatre in London in the late 1950s is particularly well documented in her papers at the British Library. A thick folder full of letters from professed 'ordinary folk' can be found in the Olivier archive, written to support Leigh in her campaigning and commend her for her bravery. Within this folder are bundles of theatre ephemera sent to her from various supporters, press cuttings documenting her actions, and dozens of congratulatory telegrams from famous and non-famous persons alike reacting to her brief protest about the St. James's Theatre in the House of Lords in July, 1957.26

Information about some of these activities can be found in narrativised accounts of Leigh's life in her numerous biographies. But accessing such events through the archive infuses them with a distinct sense of immediacy. Such archival encounters initiate what Helena Michie and Robyn Warhol describe as a 'metonymic chain by which those looking at, holding, or researching' archival materials' may 'feel asymptomatically closer to the historical reality from which the objects derive'.27 The archival reader is able to over-turn press clippings and personal correspondence one-by-one, but also to disorder their archival arrangement once outside the reading room, comparing and contrasting each fragment and piece of paper and, in some instances where permission is granted, rearranging collated digital photographs of 
archival material. These kinds of materials can describe an event in Leigh's career - such as a business venture, or an interaction with a fan - from multiple vantage points and through multiple languages; those of the financial record, or the personal letter, or the private act of scrapbooking. At the same time, the collation of these languages tells a secondary story about the way the creators of a collection have selected which media coverage and which points of correspondence to retain to frame each particular event or memory. Whilst it is problematic to assume that in an encounter with a personal archive we are straightforwardly encountering original order ('the final order given to [a body of records] by their creator' 28 ) given the interventions of varied custodians (families, estates, archivists), such materials nevertheless help us to conceptualise networked archival 'moments' in Leigh's working life which were consciously retained. The St. James's Theatre campaign is one such brief and intense moment in Leigh's late career. The archive presents the opportunity to place such moments within a larger reading of Leigh's entire career, enabling the researcher to identify trends in Leigh and her collaborators' practices and attitudes towards different kinds of labour and those diverse activities worthy of retaining within her archival record.

Off-screen 'work' is only one part of the way that the archive represents labour, however. For the remainder of the discussion, I return to my initial focus on performance and labour. I consider how in particular Leigh's role in the film adaptation of Streetcar might be reconceptualised through a focus on the archival documentation.

\section{Archiving screencraft}

The second of the two specific archival artefacts I started with, the 'right not good' note, seems to resist an understanding of Leigh's screen charisma as spontaneous, 'natural' and effortless - an idea that, as already suggested, both helped and hindered her across her career. 
Karen Hollinger's work on Hollywood acting has highlighted the sustained lack of critical attention to the work of film actresses, noting that acting has rarely been under-stood as a "“systematic or standardized process" that can be carefully examined with some objectivity by scholars'. Instead, film star acting has been presented as 'an intuitive, quasimystical, elusive art that is the particular individualized practice of particularly gifted individuals who consider it an almost religious experience.'29 This has resulted in an understanding of film actresses, more so than male performers, 'not as skilled crafts-women, but rather as screen goddesses naturally gifted $[\ldots]$ with beauty and charisma'.30

John Stokes' research into Leigh's preparation for her stage and screen roles offers an initial response to unpicking these kinds of assumptions, confronting a reductive interpretation of screen performances as de-skilled charisma. Stokes notes the research that Leigh undertook around specific roles, for example, reading histories and literature about characters like Cleopatra, and her engagement with new kinds of training later in her career to turn her hand to new modes of performance, taking singing and dancing lessons, for example, for the musical Tovarich in the 1960s.31

Leigh's archives contain a range of materials which present a network of other ideas about her approach to performance as craft and to screen and stage work as a 'systematic' process of careful, detailed preparation. Far from offering any definitive and direct statement from her own pen upon the subject, however, the archive presents more indirect ways of accessing her approach to performance. Within her personal archive at the V\&A few distinct 'treatises' on screencraft are to be found.32 More often than not, Leigh's own voice is relatively absent. Rather, the archive is constituted by clusters of materials that indirectly gesture towards her screen and stagecraft in telegram correspondences, photographs on set, annotations on 
scripts, preserved fan letters, snippets of reviews cut and pasted into albums, and one-sided replies to unseen letters. The retention of a plethora of such material is representative of the multifaceted traces of a working stage and screen life, which range from the specific (such as detailed written exchanges with directors) to the more generalised material (such as stacks of short letters and telegrams from a very wide range of known and unknown correspondents). Many such materials are ordered in her V\&A collections in a subsection titled 'Material related to Vivien Leigh's career', which includes named production files related to specific films and plays. These files contain a range of items loosely grouped around each production, inclusive of financial information, fan letters, personal correspondence and photographs. Sifting through these materials offers insight into the labour of creating a specific performance as it intersected with Leigh's collaborators, confidants, critics and fans.

Examining screenplays contained within such collections is one immediate starting point for gaining a degree of access to the labour of performance. In surveying Leigh's V\&A archive, Kate Dorney and Maggie B. Gale suggest that her collection is 'light on annotated scripts'33 in contrast to the papers of other actors, with a far greater amount of correspondence. Her papers within the Olivier archive at the British Library do contain some script material, however, which features her hand-written annotations. These include script materials for School for Scandal (1949), where she notes additional stage and performance directions to '1st \& 2nd quarrel scenes + screen scene for Miss Vivien Leigh'. Her annotations include specific suggestions for how she should use the space and perform through her body, noting that her character should be 'strutting around and fanning herself'. Elsewhere she adds commentary that the dialogue should be delivered 'slower - then laugh'.34 Other archival materials that feature no direct words or annotations from Leigh herself are nevertheless able to point towards her attitudes towards her screen and stage craft. 
Scrapbooks in her papers at the British Library feature press clippings that comment explicitly on the labour of her performance and the physical strain of playing Scarlett O'Hara during her work on $G W T W$, for example, stressing the intensity of her dedication to the part. A cutting from the New York Herald from June 1939 recounts:

Playing Miss O'Hara is a tough job. Miss Leigh has been more aggressive here. People at the studios say that she would have been justified in assuming a complete, Garbo-esque aloofness because she probably had worked harder and under a greater strain than any other actress in picture history. 35

Further clippings emphasise the intense physicality of the role and the endurance involved in filming this kind of large-scale production, but frame the experience as driven by Leigh's commitment to the authenticity of the role rather than positing Leigh as a victim of studio of directorial exploitation. A clipping from Screen Pictorial in July of the same year notes that: 'In some early scenes she refused a stand-in and baked herself under hot floodlights for eight hours a day to insure perfect lighting. She kept up her stiff pace of wardrobe-fittings and other appointments until nine each night'.

Beyond text-based materials, images retained within Leigh's collections offer further ways of reading and interpreting her approach to preparing her performances. The idea of Leigh's 'hard graft' was a significant part of the narrative that was created by David O. Selznick to support and endorse her casting as Scarlett O'Hara. Reports like those quoted above frequently noted her exhaustion and the extremes to which she pushed herself, labouring to 'be' Scarlet. Leigh's more directly personal documentation of this process can be found in photographic material. There is, for example, a small black and white shot of Leigh on set of 
GWTW contained within her papers at the British Library. The image self-consciously constructs a portrait of a labouring star on Leigh's own terms. It shows a grimy looking Leigh in a tattered Tara costume, slumped on a bench with a cloth in her hands, raised eyebrows, looking determined. 'P.T.O' is written in Leigh's handwriting in the bottom right hand corner; on the reverse is written: 'Picture of a v dirty girl - this is how your "celestial" one looks in the remains of "Tara" just before going to see Rhett [...] (made with my camera)'. Amidst the flirtatious exchange, her body is positioned as tool for and testament to her creative labour both on and off the screen.

It is within correspondence predominantly, however, that Leigh's archives offer traces of the detailed development of her performances. In relation to her role in Streetcar, correspondence reveals her sustained attempts to position her performative craft in the 'right' way to off-set her status as glamourous, 'good' star body. Contextualising the 'right/good' extract within Leigh's V\&A archive more broadly offers detail about her collaborative work on the screen adaptation of Streetcar, where she translated her role as Blanche whom she had been playing in the London production of the play (directed by Olivier) since October 1949. The film's director Elia Kazan stated in an interview for Cahier du Cinema that he decided to film the play 'as it was because there was nothing in it to change'.36 Kazan's claim obscures the significant changes made to characterisation and the key events in the film in response to censorship restrictions under the Motion Picture Production Code, including the removal of direct references to rape and homo-sexuality. But it also omits his detailed work with Leigh herself in consulting on how Blanche was to be interpreted and how to work with and around these censorship restrictions. 
The archival story of this collaboration begins with an undated copy of a cable from Leigh to Kazan in New York requesting that he attend a performance on the play in London before she left for America, 'IN CASE YOU FIND ANYTHING YOU MIGHT FEEL ADVI-SABLE TO TALK OVER BEFORE STARTING PICTURE'.37 Her request defers to his directorial intentions for the adaptation, but posits it as collaborative from the outset. She informs him that she hopes 'SO MUCH THAT WE SHALL WORK TOGETHER' and instigates a dialogue on the play as a whole to contextualise her current approach to and interpretation of the role. Kazan was apparently not able to make it to London, but the archive contains another undated letter to Leigh explaining his absence and outlining a range of key points for discussion. Given that the letter references Kazan's plans to 'leave the east August 3rd'38, and makes reference to previous detailed exchanges about the play, it appears to have arrived after Leigh had written to Kazan (addressing him by his nickname 'Gadge') in mid-June of 1950. The type-written archival copy of this letter, seemingly based on the handwritten pencil notes also contained within this collection, further illuminates the collaborative process she instigated with Kazan.

Leigh initially informs Kazan that she has 'read the script three times', and proceeds to immediately excuse this labour as marginal, claiming that she 'couldn't do more on account of having had a great many other things to do just recently'39, suggesting to Kazan that her early role preparation was normally more extensive. She proceeds to include a list of 'the notes as I jotted them down' on her thoughts about the script and its problems. These are listed by scene number moving chronologically through the narrative, formalising her reactions as she has read and re-read the material and concluding with a final 'P.S.'. Her notes gesture to previous discussions about edits and additions ('Our cuts in Scene 2 with STANLEY helpful perhaps'), and show her ability to skilfully track changes across different 
incarnations of the script, noting potential repercussions for the larger structure of the text and for the details of characterisation.

Leigh informs Kazan, for example, that in Scene 3 she has 'noticed change in Stage Directions N.Y. Script - why added dialogue in Scene with MITCH - prefer it as before if poss'. Elsewhere she questions changes to dialogue affected by other deletions, and offers character readings tied to particular lines or interactions she sees an integral to the adaptation, such as the following:

Scene 10 - Extremely attached to "may I rest my weary head on your shoulder"- to prove how complet[sic] her dream world is - STANLEY'S voice should bring her back to reality with a shock and for a second she does not realise what has become of her imagined company of friends. What is wrong with Scene with STANLEY as in play?40

Leigh's letter also shows a nuanced ability to think in intermediary terms between play and film, with the keen eye of an adaptor. She comments on how best to compress and emphasise elements from the play for the shorter running time of a motion picture, questioning changes to 'Scene 11', for example, where 'extra length most unfortunate at this time in picture'. She suggests that additional dialogue is not required where performance can be utilised to more economically communicate key information: 'if EUNICE conveys her belief in the rape in her line to STELLA - implication just as strong as added dialogue surely'. At the end of the letter she suggests a more significant structural and media-specific change, asking whether Kazan would agree to the use of a flash-back to replace 'the glimpse one gets of BLANCHE's early life in Scene 6', enabling it to 'be seen and not merely heard'. She 
explains that 'in the movie medium if it is a choice between a flash-back and endless dialogue, I am sure the former is the least undesirable of the two - do you agree?'.

Whilst Kazan ultimately chose not to include flashback scenes (in his response to her letter, he states that he 'hates flashbacks'41), in making the film he employed cinematography and set design in ways that similarly foregrounded the distinctly visual and symbolic register available to moving image storytelling in contrast to theatre. The adaptation makes use of medium shots and muted lighting to restrict the characters within claustrophobic frames and reflect their increasingly constricted experience, and offers the audience a far closer look at Blanche's face in the lamplight than a stage performance could ever facilitate. Although their selected techniques differed, therefore, Leigh displays some similar skills as an adaptor, considering how to handle the transposition of narration from playscript to screen with a strong awareness of what Linda Hutcheon in her work on adaptation terms the 'showing mode'42 of film. Her insistence upon exploiting the ability of film to enable non-linear and multi-location content to 'be seen' is echoed in Kazan's inclusion of locations beyond the single setting of the play, for example, moving beyond the bounds of the Kowalski's apartment to show the railway station, the docks, the bowling alley and the pier.

In responding to Leigh's initial phone call, Kazan's undated letter mentioned earlier shows the influence of her suggestions, or at least his willingness to communicate his intentions to solicit her ideas and act upon her advice. He writes, for example, that her 'remarks and concerns gave me a jolt', causing him to read the script prepared by Tennessee Williams and Oscar Saul attentively for the first time having not yet 'really sat down alone and really look at' what they had written. Three times in the letter he reminds Leigh to send 'her letter'; 
'PLEASE don't forget the letter'; 'write me immediately', insisting that she outline her criticism and concerns in full and earnestly soliciting her critical voice.43

Whilst Kazan publicly professed to have avoided alteration in adaptation, therefore, his dealings with Leigh testify to how her development of her screen performance constituted an ongoing creative collaboration, one that incorporates her attempts to structure an interpretation of Blanche in the specific context of her struggle to craft an authentically 'right' rather than glamorously 'good' physical aesthetic within a broader reconceptualization of the framework of the film as a whole. This kind of archival material speaks more broadly to the archive's potential to deconstruct the film performance by mapping out its prehistory, examining it as a process of personal and collaborative development and structuring. Fragments of this process can be pieced together through notations and correspondence and placed in dialogue with the annotated scripts, clippings and photographs discussed earlier. The retention of the material traces of Leigh's screencraft in this way thus presents an alternative account of the de-skilling of the work of the star actress.

\section{Archival agency and self-fashioning}

In her work on Gloria Swanson's collections at the Harry Ransom Centre, Anne Helen Peterson suggests that star archives have value because they might offer a rebuttal to the assumed 'lack of agency generally attributed to stars working under the studio system', which has resulted in their relegation to positions of 'dupes, naïfs, or, quite simply, "the product."" 44 The Leigh archive retains materials that support this kind of rebuttal, in her own hand and in the correspondence of others. The retention of more personal material like the 'right/good' note, never intended for public consumption, alongside mass produced and public material within her personal collections similar to the LOOK magazine cover, suggest 
a desire to foreground the diversity and details of her professional craft for future spectators of her archive.

Petersen makes the case for substituting the term 'archive' with the term 'collection' 45 to account for this process of selection and shaping, suggesting that:

semantically, archive implies the collection of all materials of an organization, company, or individual, including all business records, memos, and extraneous materials - the good and the bad, the interesting and the boring. Archives are repositories, not generally showcases. A 'collection' (sometimes called a 'special collection') implies some form of editing, whether on the part of the gifting organization, the individual, the individual's family, or the acquiring organization.46

Peterson highlights the materials that appear to have been consciously omitted and retained within Swanson's collections, noting aspects that seem to have been placed 'like Easter eggs, for scholars, journalists, and fans to find'.47 Amelie Hastie further argues that stars as archivists of their own creative lives 'perform and produce'48 knowledge through such archiving, which the researcher in turn interprets when seeking to access their subjectivities through the archival traces they leave behind.

It is tempting to claim that the preservation of Leigh's labour process through her material collections constitutes a direct act of archival self-fashioning, where Leigh as the subject and originator consciously creates a diverse material account of her working practice. It is problematic, however, to straightforwardly read archival collections as reflections of the personality or presumed intentions of their subject. Leigh's personal assistants, for example, 
were seemingly responsible for the collation and ordering of many aspects of her paperwork in the archive - particularly fan material and correspondence, which frequently bear the marks of their shorthand annotations. This potentially places Leigh at a greater distance from the particular pathways or modes of reading her working life that we may find present in the archival order of her material legacy (in general, archival institutions attempt to preserve original order where feasible as a fundamental archival principle). Further, her collections, like most archives, have been subject to a degree of re-ordering and, in the process, a degree of resignification as they pass from private into public repositories, whose choices in arranging material by subject heading for the purposes of cataloguing inescapably impact on how such collections make meaning.

Material traces of Leigh's labour acquire a particular kind of urgency for the archival researcher investigating her career given that, as previously mentioned, she never produced an autobiography (a standard practice for many stars of her era). If as Peterson asserts 'memoirs are perhaps the most explicit form of self-authorship - an attempt to author the public remembrance of the self'49, the total absence of any memoir in Leigh's star legacy would seem to leave a distinct absence for scholars seeking to reclaim or revisit Leigh's career and cultural legacy. Leigh did not produce the kind of focused, self-authored reflective documentation that enabled some female stars to "produce their own theoretical and historical models about their work and the industries they have been engaged in'.50 This prompts us to approach the archive as a unique access point to this 'absent' testimony and self-authored account of star labour and agency. Leigh's archive does not submit willingly to this role as substitute, however. Her voice is much more markedly absent than present within her collections. Her 'diaries' held at the V\&A, for example, are appointment diaries, offering the eager researcher relatively little access to the more intimate, confessional details that are 
usually associated with the term. There are few examples of her sustained reflection upon her career, her roles, or her experience of the international film industries with which she was engaged within her own papers.

In the absence of more overt instances of her voice, however, Leigh nevertheless pro-duces presence in the archive through acts of retention, preserving complex inter-actions with directors like Kazan alongside the more everyday debris of performative craft (script annotations, clippings, personal photos). Such spectral presence can be used in a biographical mode to illuminate Leigh's agency in past events (making her visible in the pre-production of Streetcar and its particular navigation of censorship restrictions in adapting characters and settings). But beyond this, it encourages the researcher to interrogate the very materiality of how the accounts of such events are presented and encountered in archival form, reading Leigh as an archival presence through her documentation of these events and their retention in disparate forms. In regard to Leigh's V\&A collections, Dorney and Gale suggest that whilst researchers 'cannot be certain of her role and intention in the gathering and keeping' of materials, 'the breadth and depth of extant material, beyond the usual scrapbooks of reviews and interviews, is extraordinary'.51 V\&A Theatre and Performance curator Keith Lodwick in his public lecture at the Vivien Leigh centenary celebrations at the V\&A in 2015 further suggested that Leigh seemed to have quite consciously kept everything from her working life together in one place. Indeed, Leigh's V\&A archive in contrast to those of other classical stars is uniquely comprehensive, containing some ten thousand items. Whilst it is difficult to make more specific claims for Leigh's hand in exactly how the materials can be read within the archive in regard to order, therefore, by achieving such meticulous 'breadth and detail', Leigh exercised significant agency in forming, encouraging and directing the formation of a comprehensive record of her star labour. 
Reading Leigh's archival collections comprehensively, therefore, rather than overemphasising specific fragments (such as the media focus on the 'steamy' love letters, mentioned earlier) can foreground her agency in a way that does not demand that the archive constitute intimate and direct 'confession'. The record of her career mapped out through the materials touched upon across the article creates a spectral map of her activities, which in turn produces Leigh as creative labourer as an active presence. Leigh can thus be re-read and reframed as a multifaceted figure - business woman, protester, financier, actress -whose archive seems to pointedly attest to the idea that the working life of a female star during this period, defined by a network of roles and labours, is not easily captured in more standardarised (auto)biographical narratives.

\section{Notes}

1. Hereafter $G W T W$.

2. Hereafter Streetcar.

3. These include Gwen Robyn's Light of a Star: The Sensitive and Intimate Story of the Bewitch-ing Vivien Leigh (1968); Alan Dent's Vivien Leigh: A Bouquet (1969); Anne Edwards' Vivien Leigh: A Biography (1977); Alexander Walker's Vivien: A Life of Vivien Leigh (1987); Angus McBean's Vivien Leigh: A Love Affair in Camera (1989), and Kendra Bean's Vivien Leigh: An Intimate Portrait (2013).

4. Antoinette Burton, 'Introduction: Archive Fever, Archive Stories', in Archive Stories: Facts, Fictions, and the Writing of History, ed. Antoinette Burton (London: Belknap Press of Harvard University Press, 2005), 7.

5. Alice Yaeger Kaplan, 'Working in the Archives', Yale French Studies: on Texts and Institutions 77 (1990): 103. 
6. The Circle's Facebook page marks the reinstatement of the Club in February 2014, initially founded by UK based fans in the 1960s. As of January 2018, the page has around 4,800 fol-lowers. Source:

https://www.facebook.com/pg/vivienleighcircle/about/?ref=page_internal

7. Hannah Ellis-Petersen, 'Laurence Olivier's Steamy Love Letters to Vivien Leigh See Light of Day', The Guardian, 2 February 2015, n.p.

8. Danae Clark, Negotiating Hollywood: The Cultural Politics of Actors' Labour (Minnesota: University of Minnesota Press, 1995), xi; xii.

9. Sean P. Holmes, 'The Hollywood Star System and the Regulation of Actors' Labour, 1916-1934', Film History 12, no. 1 (2000), 97.

10. Ibid. 98.

11. Ibid.

12. Exhibition leaflet, Vivien Leigh: Public Faces, Private Lives (York: Treasurer's House, 2015).

13. Kate Dorney, 'Public Faces/Private Lives: Performing Vivien Leigh', in Vivien Leigh: Actress and Icon, ed. Kate Dorney and Maggie B. Gale (Manchester: Manchester University Press, 2018), 25.

14. Ibid., 26; 37.

15. Leigh's career was forged through her professional training at The Royal Academy of Dramatic Art, and her ongoing training with voice and singing teachers, which she spoke of publicly.

16. Qtd. in. Gavin Lambert, On Cukor (New York: Rizzoli, 2000), 115.

17. Qtd. in Hugo Vickers, Vivien Leigh: A Biography (London: Penguin Books, 1988), 206. 
18. Qtd. in Lewis Funke and John E. Booth, Actors Talk About Acting: Fourteen

Interviews with Stars of the Theatre (London: Random House, 1961), 242.

19. Barry King, 'The Star and the Commodity: Notes Towards a Performance Theory of Stardom', Cultural Studies 1, no. 2 (1987): 154.

20. Ibid.

21. The exhibition featured some 50 portraits spanning her career on stage and screen.

22. A Streetcar Named Desire Production File, Vivien Leigh Archive, V\&A Theatre and Performance Collections, THM/433/4/3/11.

23. See Mark Glancy’s survey of negative British press criticising Leigh's connection to Holly-wood during this time in his book Hollywood and the Americanization of Britain from the 1920s to the Present (London: I.B. Tauris, 2014).

24. Kendra Bean, Vivien Leigh: An Intimate Portrait (London: Running Press, 2013), 89.

25. 'Actress-Producer' (1958) Edinburgh Evening News, 18 September. British Library Manu-script Collections, Laurence Olivier Archive, ADD MSS 8064.

26. See Add MS 80627-80630: Olivier Archive, British Library, vols. DCCCLXIIDCCCLXV.

27. Helena Michie and Robyn Warhol, 'Adventures in the Archives: Two Literary Critics in Pursuit of a Victorian Subject', Victorian Studies 52, no. 3 (2010): 416.

28. Jennifer Douglas, 'Original Order, Added Value? Archival Theory and the Douglas Coupland Fonds', in The Boundaries of the Literary Archive: Reclamation and Representation, ed. Carrie Smith and Lisa Stead (Farnham: Ashgate, 2013), 51.

29. Karen Hollinger, The Actress: Hollywood Acting and the Female Star (New York: Taylor \& Francis, 2006), 4.

30. Ibid. 
31. John Stokes, 'An Actress Prepares', in Vivien Leigh: Actress and Icon, ed. Kate Dorney and Maggie B. Gale (Manchester: Manchester University Press, 2018), 69-93.

32. Where such material exists, it is most often in the form of first-person articles for fan magazines and other periodicals where Leigh has been asked to reflect on her career or her profession as an actress for publicity purposes.

33. Kate Dorney and Maggie B. Gale, 'Vivien Leigh, Actress and Icon: Introduction',I n Vivien Leigh: Actress and Icon, ed. Kate Dorney and Maggie B. Gale (Manchester:

Manchester Uni-versity Press, 2018), 15.

34. School for Scandal typed extract, Laurence Olivier Archive, British Library, ADD MS 80636.

35. Cutting from The New York Herald, 27 June 1939. Laurence Olivier Archive, British Library, ADD MS 80669.

36. William Baer, ed., Elia Kazan Interviews (Mississippi: University Press of Mississippi, 2000), 95.

37. Cable to Elia Kazan from Vivien Leigh, n.d., Vivien Leigh Archive, V\&A Theatre and Per-formance Collections, THM/433/4/3/11.

38. Letter to Vivien Leigh from Elia Kazan, n.d., Vivien Leigh Archive, V\&A Theatre and Per-formance Collections, THM/433/4/3/11.

39. Letter to Elia Kazan from Vivien Leigh, 16 June 1950, Vivien Leigh Archive, V\&A Theatre and Performance Collections, THM/433/4/3/11.

40. Ibid.

41. Letter to Vivien Leigh from Elia Kazan, n.d., Vivien Leigh Archive, V\&A Theatre and Per-formance Collections, THM/433/4/3/11.

42. Linda Hutcheon, A Theory of Adaptation, 2nd ed. (London: Routledge, 2013), 33. 
43. Letter to Vivien Leigh from Elia Kazan, n.d., Vivien Leigh Archive, V\&A Theatre and Per-formance Collections, THM/433/4/3/11.

44. Anne Helen Petersen, 'What to do with a Coffin Full of Sugar: Gloria Swanson, Kenneth Anger, and Self-authorship in the Star Collection', The Moving Image, 13, no. 2 (2013): 95 .

45. The term 'collection' has itself been highly contested in archival theory: see Yeo (2012) for a detailed discussion of distinctions and connections between the terms 'fonds' and 'collections' in critical archival discourse.

46. Petersen, 'What to do',84-85.

47. Ibid, 85 .

48. Amelie Hastie, Cupboards of Curiosity: Women, Recollection, and Film History (Durham: Duke University Press, 2007), 224.

49. Peterson, 'What to do', 92 .

50. Hastie, Cupboards,3.

51. Dorney and Gale, 'Vivien Leigh', 11. 